\title{
The Local Social and Environmental Impacts of Smallholder-Based Biofuel Investments in Zambia
}

\author{
Laura German $^{1}$, George C. Schoneveld ${ }^{1}$, and Davison Gumbo ${ }^{1}$
}

\begin{abstract}
High oil prices, recent commitments by industrialized countries to enhance the use of renewable energy, and efforts by developing countries to stimulate foreign investment as a pathway to development have fueled high levels of interest in the biofuel sector throughout much of sub-Saharan Africa. Zambia is no exception. A large, land-locked country with high pump prices and vast tracts of land considered by many to be "degraded" or "underutilized," investor interest in the sector has remained high despite uncertainties associated with unproven feedstocks and market fluctuations. While investment in multiple feedstock and production models may be observed, one of the primary investments has been in jatropha outgrower schemes in which small-scale farmers grow feedstock on contract with domestic and foreign investors. We assess the history and evolution of the largest such scheme in Zambia, as well as the social and environmental impacts in two districts with large numbers of outgrowers. Findings suggest that, although such a production model may hold promise for enhancing rural livelihood benefits from the emerging biofuel sector, to date, small-scale farmers have borne the brunt of the risk and uncertainty that are the trademarks of this emerging industry. We conclude with a discussion of options to minimize forest conversion and protect farmers against high-risk investments, while harnessing the potential of this business model for enhancing rural livelihoods in Zambia and elsewhere.
\end{abstract}

Key Words: biofuels; jatropha; outgrower scheme; Zambia

\section{INTRODUCTION}

Preoccupation among industrialized countries with security of energy supply and global climate change and developing country interest in improving the balance of trade and capturing value from the global carbon market have placed biofuels firmly on the map of global land use change. Much of this change is occurring in developing countries where larger tracts of land may be accessed at lower economic and opportunity cost (Mathews 2007). In the last decade, countries across southern Africa have quickly positioned themselves to benefit from the emerging market in biofuels by developing legal and institutional frameworks for biofuels to attract foreign investors (Department of Minerals and Energy 2007, MEWD 2008, República de Moçambique 2009). Zambia has proceeded in kind. Landlocked and highly dependent on imported petroleum, biofuels are an attractive option not only for generating much-needed foreign exchange, but for domestic energy security. Unlike business models observed in other African countries (FIAN 2010; Schoneveld et al. 2011), large-scale biofuel investments in Zambia have largely focused on smallholder production models, in part to defray the higher than anticipated production costs (German and Schoneveld, in press). Given that such schemes are being framed as a "win-win" solution to the problems associated with large-scale land acquisitions on the continent (von Braun and Meinzen-Dick 2009), it is essential to gain a deeper understanding of the conditions under which they may yield sustainable benefits in the context of the emerging biofuel industry.
We explore the evolution of Zambia's largest jatropha outgrower scheme, with an estimated 25,000 contracted farmers nationwide, and the social and environmental impacts that have accrued to date. Jatropha, a perennial crop with seeds yielding nonedible oils, has rapidly gained popularity in Africa due to its purported adaptability to suboptimal growing conditions and ease with which the crude oil may be used as a liquid fuel. Following a brief introduction to the evolution of the biofuel sector in Zambia, we present the methodology. Findings are summarized in two key sections, one summarizing the history and evolution of the scheme, and the other its social and environmental impacts. We conclude with a reflection on findings and lessons learned for policy and governance.

\section{BACKGROUND}

Social and environmental impacts of outgrower schemes and biofuel feedstock production in southern Africa Outgrower schemes are a form of contract farming ${ }^{[1]}$ in which farmers grow crops on their own land under contract to largescale enterprises in exchange for various price guarantees, inputs, and services (Abwino and Rieks 2007, Glover 1990). Outgrower schemes may be implemented independently from or in conjunction with nucleus estates controlled by the contracting company under nucleus-outgrower schemes (Glover and Kusterer 1990). They are distinct from independent smallholder production, which lacks contractual purchase agreements with (and corresponding support from) industry (Brittaine and Lutaladio 2010). Considering the 
interest in these schemes as a means to address the financial and technological limitations to agricultural intensification in Africa, it is crucial to understand the conditions under which they yield positive outcomes for smallholders.

Reviews of contract farming and outgrower schemes in subSaharan Africa identify a number of important determinants of social outcomes. These include the nature of the crop (shaping up-front investment levels and labor requirements), land tenure and availability (shaping willingness to invest and to participate), and farmers' income diversification (shaping farmers' bargaining power and exposure to risk) and prior experiences with large-scale investors (shaping levels of awareness at the negotiation stage) (Lamb and Muller 1982, Glover 1990, Porter and Phillips-Howard 1997). They also include investor practices related to staffing and communication, product grading and pricing, and contract terms (e.g., input provision arrangements, transparency, barriers to exit), as well as contextual factors, such as pricing policies (which exert upward or downward pressures on rent capture by smallholders) and diversification of market outlets (Glover 1990, ECI Africa Consulting 2006, Freeman et al. 2009, CSBF 2010).

As for actual outcomes, one study in Zambia identified a number of benefits to farmers, including employment, input support, guaranteed markets, and grants for community projects (CSBF 2009). Yet shortcomings in outgrower contracts have also undermined the potential to generate meaningful social benefit. These include low prices, unfair input and produce pricing mechanisms, under-grading and under-weighing of farmer produce, unfair input credit conditions, and punitive loan recovery methods (CCJDP 2006). Limited transparency in agreements has also led to misunderstanding among outgrowers of what they are signing up for, with the costs of extension services generally deducted from prices paid to farmers without this being understood by farmers. This undermines their ability to monitor these services and ensure value for money (ECI Africa Consulting 2006). The absence of a comprehensive government policy on out-grower schemes and lack of government oversight of the operations of investors have also made farmers vulnerable to exploitation by outside investors (CCJDP 2006).

In the biofuel sector, a recent study found $72 \%$ of growers to be dissatisfied with the outgrower scheme because contracting companies failed to provide the follow-up support outlined in the contract or because of low prices (CSBF 2010). Contracts in excess of 30 years in some cases have the effect of transferring the right to make production decisions to companies for the period the contract is in effect. The muchdebated concerns about farmers converting land for food production to biofuel feedstock, on the other hand, were not confirmed by this study. Whereas this study identified inadequate labor for jatropha as a constraint during periods when labor requirements for food crops are high (CSBF 2010), another study of household activity calendars in Zambia suggests that most jatropha activities can be done in periods when other agricultural activities are not at their peak (Freim 2008). A study by Loos (2009) in Mpanda District, Tanzania also supports the observation that, under the right conditions, jatropha does not displace food crops; however, it may lead to new land being taken into production, both directly for jatropha and indirectly for food crops displaced by jatropha. This points to the importance of looking at indirect land use change when assessing the impacts of biofuels, whether produced under small- or large-scale business models.

\section{Evolution of the biofuel sector in Zambia}

Driven by private sector interests, the Zambian biofuel industry experienced strong growth in the mid-2000s, much of it speculative and based on feedstock and production systems yet to be proven in Zambia. This character contributed to the failure of many early initiatives during the global economic downturn, causing some investors to pack their bags and leave Zambia and others to go into hibernation. Other investors have scaled back and taken a more cautious, knowledge-based approach in which future expansion will draw on lessons learned from early failures and from systematic research into the agronomics and organizational arrangements for contracting and supporting smallholders. Thus, the sector is still in its infancy, characterized by experimentation in feedstocks and production models (CSBF 2009). Jatropha is a small tree or large shrub 5-7 $\mathrm{m}$ in height with seeds yielding a nonedible oil that can be used for liquid engine fuel either directly (pure or in blends) or through pyrolysis, microemulsification or transesterification (Achten 2010). Although it is adaptable to a wide variety of ecological conditions and can withstand drought and low-nutrient conditions, optimal fertilization and irrigation application can increase seed and oil yield (Heller 1996, Achten 2010). According to one source, "The considerable lack of insight in genetics, input responsiveness and agronomy of jatropha makes yields poorly predictable ... Consequently, the economic viability of this, basically wild, plant is still highly uncertain" (Achten et al. 2009:164).

Other than the alternative energy ambitions described in the National Energy Policy, Zambia currently has no policy on biofuels. Key policy documents outlining current (but evolving) government thinking on the sector include the draft Long-Term Renewable Energy Strategy and draft Biofuels Industry Strategy. Although the private sector, through the Biofuels Association of Zambia (BAZ), is pushing for policies and incentives to kick-start the industry, not all investors are awaiting these commitments before investing. Some companies are pushing forward irrespective of government commitments in an effort to capitalize upon the European market, in the belief that they will be able to reap profits far higher than those currently achievable through food crops. 
Most of these investors are focusing on Jatropha curcas as a feedstock. Whereas some of these investments are based on a large-scale plantation model, others rely on contracting large numbers of small-scale farmers to produce biofuel feedstock to be processed for domestic consumption and export. The latter finds support in the draft Biofuels Industry Strategy, whose objectives include "uplifting the agricultural sector ... by promoting farming in areas that did not have market access for their produce and by creating a development balance between disadvantaged farming areas and commercial farming areas" and "to stimulate rural development and reduce poverty by creating sustainable income-earning opportunities" (MEWD 2008). Nevertheless, a great deal of uncertainty remains as to the nature of investor-smallholder contracts and support services required to make these goals a reality.

The largest such initiative is Marli Investments Zambia Ltd., a joint venture between South African, Indian, and Zambian investors. Although the company's chairman is reportedly the former Zambian President, Dr. Kenneth Kaunda (Freim 2008), South African company CO2 Energy claims to hold 50\% equity shareholding in Marli and 100\% off-take rights of all jatropha biomass produced over and above the required feedstock for Zambian biodiesel consumption (CO2 2010). Marli initiated operations in 2004 in several districts of Central Province and at the time of writing operated in all of Zambia's nine provinces (GEXSI 2008, Desai 2009), with plans to operate in all districts in Zambia in the near future (Desai 2009). Given the apparent volatility of Marli investments, it is unclear whether such aims are realistic or contingent upon additional finance. At the time of research, the company claimed to have signed contracts with approximately 25,000 outgrowers and distributed 12,650,000 seeds/seedlings, and estimated to have more than 11 million trees and an estimated 125,000 ha under contract (Freim 2008, CO2 2010; Desai, personal communication) ${ }^{[2]}$ This was made possible through the deployment of 96 field officers and more than 180 coordinators (presumably the "contact farmers" observed in fieldwork) working to promote the project (Desai 2009). Marli also runs a nucleus estate of 12,000 ha with combined feedstock for producing an estimated 5 million liters per annum, almost enough to satisfy the widely anticipated $2 \%$ blending target for biodiesel, which required an estimated 6 to 7 million liters (Desai 2009; Desai, personal communication). The company has reportedly secured a total of 600,000 ha from the Zambian government for the core estate (CO2 2010). In addition to expanding the area under cultivation, the company was planning to establish a processing plant in Kabwe District and to produce a blended fuel in partnership with the Indeni Petroleum Refinery in Ndola to target the domestic market primarily. The company has focused on securing feedstock supplies as it awaits blending targets and outside investments on the order of $\$ 25$ million to finance feedstock production and refining (GEXSI 2008, Desai 2009). While at the time of research all investments had been financed by the board of directors and shareholders, meeting future investment targets will depend on external finance (Desai 2009). Thus, contracting is proceeding apace despite the absence of policies and financing to secure long-term commitments to contracted farmers.

Marli has adopted an outgrower model for a number of reasons. The $\mathrm{CO} 2$ website provides a number of justifications for the outgrower model, including "staff logistics, housing, local land ownership pressure, government policy, tribal council sentiment, areas of land available, cost of land, approval red tape, and long-term stability and support by farmers, tribal council, chiefs and the government." From interviews with representatives of Marli and other companies investing in jatropha, the high cost of labor also seems to be paramount. With seed maturing at different stages, labor needs highly seasonal, and no possibility to mechanize the harvest, this is considered the most significant cost deterring investment in large-scale plantations. The company's outgrower contracts outline a host of inputs, services, and financial incentives to be provided on loan to farmers in exchange for exclusive sales to Marli. The company has reportedly moved away from outgrower contracts and toward purchase agreements or "jatropha production agreements" as a means to reduce the risks associated with side-selling ${ }^{[3]}$ by promising less to farmers (Desai 2009; Desai, personal communication). However, in the two districts studied, no such agreements were identified, and the original contracts continue to shape farmer expectations.

\section{METHODOLOGY}

\section{Research site}

The research focused on the Northern Province of Zambia, which in addition to being the site of one of Marli's two major clusters of outgrowers, is home to other large-scale investments in jatropha and other dual-purpose feedstocks, such as oil palm and sugar cane. Northern Province is also home to a number of local enterprises seeking to process jatropha seed into soap and other by-products. The Dutch NGO SNV has supported the emergence and strengthening of these enterprises for the express purpose of finding an alternative outlet for jatropha seed and for piloting a biofuel production and processing model based on small-scale farmers and entrepreneurs. The Province is also significant for its reputation as an area with low population densities and a (more debatable) prevalence of highly degraded landscapes, the latter associated in the public imagination with the use of fire in local land use practices.

Northern Province is home to a unique form of shifting agriculture practiced by Bemba farmers called chitemene 
(Chibemba for "to cut"). The system consists of an infieldoutfield system in which branches lopped from the larger "outfield" are concentrated on a smaller "infield" and burnt to liberate nutrients for cultivation (Stromgaard 1986). Estimates by Kakeya et al. (2006) and Stromgaard (1984) indicate that outfields are in the order of seven times larger than the resulting infields (which measure from 0.2 to 1 ha). Stacked branches are burned before the onset of rains and seeds sown in the ash patches to maximize yields. Fields are abandoned following 3-4 years of cultivation due to declining returns to labor, allowing woodlands to regenerate (Sprague and Oyama 1999). The practice of lopping branches but not felling trees is a unique feature of this shifting agricultural system, enabling trees to reach reproductive age faster, as well as regeneration (Stromgaard 1986). Stumps left in place in the cultivated "infields" also allow woodlands to rapidly regenerate following plot abandonment, with full regeneration occurring within 25-50 years (Chidumayo 1987; Stromgaard 1988 and Boaler and Sciwale 1966, cited by Sprague and Oyama 1999). Efforts by colonial and postcolonial governments to encourage the Bemba to settle along roadsides and to offer incentives for maize production in permanent fields have led to significant changes in the chitemene systems, with the resulting intensification having uncertain effects on sustainability (Moore and Vaughan 1994, Sprague and Oyama 1999). Locating research in such a landscape enables the testing of oft reported benefits of orienting biofuel investments toward "degraded" landscapes with low population density, namely, that it will be possible to generate the "development" benefits of biofuels while avoiding its social or environmental costs.

Within the Northern Province, two districts were selected for field research based on the presence of clusters of Marli outgrowers and the presence or absence of alternative markets for jatropha seed (Fig. 1). The first, Chinsali District, is home to one of Marli's largest clusters of outgrowers. Although two small enterprises are beginning to take root, they are still in the trial phase, and the vast majority of farmers have found no alternative market for their seed. The second, Mungwi District, is located $34 \mathrm{~km}$ from the provincial headquarters, Kasama, and is home to a cluster of approximately 1000 Marli outgrowers (Desai, personal communication). It is also home to the most advanced of SNV-supported enterprises, with a reported capacity to purchase all of the seed in the district (but with relatively low purchase volumes at the time of research in the order of 4 tons per year). This sampling strategy enabled a consolidated analysis of variables for which responses are unlikely to vary among districts (e.g., the content of and expectations associated with outgrower contracts), while also allowing lessons to be learned from a comparative analysis of variables likely to vary across districts (e.g., economic impacts, patterns of land use change). According to the 2000 population census, population estimates for the two districts were 92,868 and 52,062 for Mungwi and Chinsali, respectively, which, given established population growth rates, can be expected to have reached 126,000 and 71,000, respectively, by the end of 2010. Households in both districts are highly dependent on on-farm income for their livelihoods, with the collection of forest products (charcoal, caterpillars, mushrooms) an important complement to agricultural income (primarily from millet, cassava, maize, groundnuts, and limited amounts of livestock).

Fig. 1. Map of Zambia with the location of the two study districts and the provincial capital.

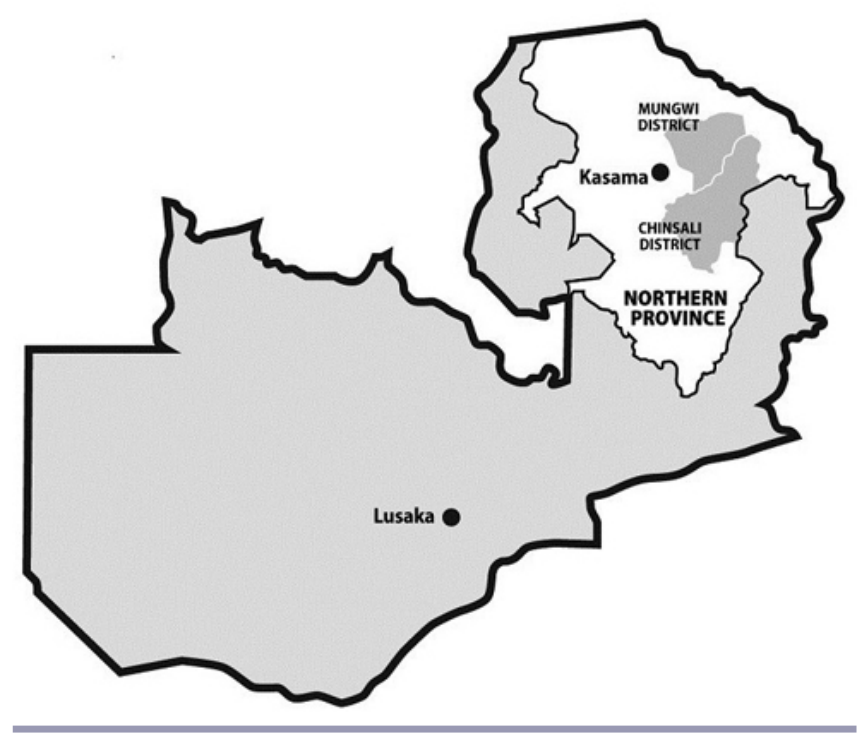

\section{Methods}

Research, conducted from May to June 2010, consisted of key informant interviews in Lusaka and field research in Chinsali and Mungwi Districts. Interviews in Lusaka included representatives of key government agencies, civil society (including SNV), and representatives of Marli Investments Zambia Ltd. At the district level, key informant interviews with Marli field officers, SNV staff, and local government helped to contextualize the study and location of different outgrower communities. Focus group discussions were then carried out in two or more villages per district to understand outgrower perceptions on the evolution and status of the outgrower scheme, land use changes, and related social and environmental impacts. Information from these discussions was then used to finalize draft questionnaires, to ensure that issues and variables of local concern and relevance were systematically captured. Household surveys were then carried out with 30 outgrower households in each district. Interviews were carried out with either male or female household members or both (based on their availability and interest) and 
registered as single interviews. This means that subsequent references to "farmers" or "growers" refer to those present during interviews. It also means that gender dimensions were captured through the questions asked rather than genderdisaggregated interviews. Where sizeable clusters of outgrowers could be found, an effort was made to interview 10 households per village from villages located in diverse locations throughout the district so as to capture diversity in the socioeconomic and biophysical context. In cases where only clusters of fewer households could be found, respondents were selected from more than three villages. Interviews with growers were conducted by the authors with the assistance of local research assistants familiar with the outgrower scheme and bilingual in both English and Bemba. To avoid subsequent problems of interpretation, questions were read by the authors in English and translated into Bemba by the research assistants, and responses were translated back into English so the authors could record responses on the questionnaires.

To assess direct and indirect land use changes occurring due to the integration of jatropha into smallholders' farms, use of remotely sensed data was considered unfeasible due to the fragmented nature of plots associated with the outgrower production model, the small proportion of farmers going into jatropha (1000 households in districts of over 150,000 residents), the difficulty of distinguishing the spectral signature of jatropha from other crops, and the cost associated with securing GPS coordinates for all the plots concerned. Thus, environmental impacts were explored through the direct and indirect land use changes reported by respondents. Although this analysis provides a general indication of the direction of land use change, data quantifying these changes should be interpreted with caution given the difficulties associated with accurately assessing plot size among respondents.

\section{FINDINGS}

\section{History and evolution of the jatropha outgrower scheme in Northern Province \\ Contractual agreements, expectations, and broken promises}

\section{Contractual agreements}

The original contracts signed with outgrowers, the only agreement governing outgrower-company relations in the research site, were for a period of 30 years. During this time, farmers are obliged to maintain their jatropha fields in production and to sell exclusively to Marli at a price to be determined by Marli at the time of sale. The consequences of such terms were captured poignantly by the Provincial Chairman of the Northern Biofuels Association, who stated the following: "Imagine at my age enter[ing] into a contract for 30 years? I will be enslaving my own offspring." In exchange for these commitments from farmers, the contracts state that Marli will make a one-off payment of approximately
US\$ 60 and pay an additional US\$ 15 per month to growers until trees mature to those farmers able to plant 5 ha $(5000$ seeds) or more. As none of the farmers were able to allocate this area of land to jatropha, field officers state that Marli agreed informally to prorate this payment for farmers cultivating 1 ha or more. Although this was never written into the contracts signed by farmers (all of which are written in English, which most farmers cannot read), it was reportedly included in the verbal translation provided by field officers. Thus, farmers would tend to expect these conditions despite the absence of any contractual obligations from the company. The contract also states that Marli will provide "seed, scions and chemicals" and services such as "extension services, marketing facilitation, transportation of inputs and produce, storage, licensing, etc." However, contracts stipulate that these will be provided on loan, to be "recovered through crop sale proceeds." Neither the cost of these inputs and services nor the interest rates on the loans are specified. Contracts also commit Marli to allocate 5\% of profits to "the Jatropha Outgrowers community" for use in "community-driven projects." Although this has the potential to lead to concrete benefits for local residents, contracts with farmers are either left unsigned or signed by field officers who mistakenly take their "Certificate of Competence" as an employment contract enabling them to represent the company. This, together with the fact that farmers were not given copies of contracts (by request of Marli, according to certain field officers), suggests that Marli is unlikely to have any legal obligation to fulfill terms of the contract should they be held accountable.

Although concerns about these contracts have been raised by civil society (CSBF 2010), only $24.5 \%$ of respondents indicated that there was anything in the contract that concerned them. Of these, the vast majority $(75 \%)$ indicated that they had never tried to shape the terms of the contract in any way. Those that did try to adjust the terms were unsuccessful in doing so; however, verbal exchanges between field officers and company representatives led to some adjustments (such as prorated benefits for farmers planting at least $1 \mathrm{ha}$ ) that were never committed to writing. Only one farmer reported that he had pulled out of the contract after signing. In an effort to understand whether this complacency resulted from limited awareness of contract terms, we verified the extent to which farmers believed different contract terms were true or false. The results, summarized in Table 1, suggest a high degree of awareness of the terms. However, their potential consequences to future livelihoods and freedom of choice are undoubtedly underrated by farmers who appear to have a limited understanding of the long-term implications of contracts should they be enforced. Given histories of failed development interventions by state and nonstate actors, farmers may also be discounting the future in the hopes of securing short-term benefits (Ferguson 1999, Cliggett et al. 2007). 
Table 1. Awareness among farmers of the terms of Marli outgrower contracts in Chinsali District $(n=30)$.

\begin{tabular}{lcc}
\hline \hline Term or Condition & \multicolumn{2}{c}{$\%$ respondents } \\
\cline { 2 - 3 } & $\begin{array}{c}\text { Aware } \\
\text { ("True") }\end{array}$ & $\begin{array}{c}\text { Unaware } \\
\text { ("False") }\end{array}$ \\
\hline $\begin{array}{l}\text { Contract term of 30 years } \\
\begin{array}{l}\text { All produce must be sold to the } \\
\text { contracting company }\end{array}\end{array}$ & 90.0 & 10.0 \\
$\begin{array}{l}\text { Training, agrochemicals, and seed } \\
\text { are provided on loan and not for } \\
\text { free }\end{array}$ & 76.7 & 3.3 \\
$\begin{array}{l}\text { The cost of these "in-kind" loans } \\
\text { are to be deducted from profits at } \\
\text { the time of harvest }\end{array}$ & 76.7 & 23.3 \\
\hline
\end{tabular}

\section{Expectations}

A major recurring theme, which may in part explain farmers' willingness to promise so much to the company, are what may be considered unrealistically high expectations among farmers. Much of this stems from statements from Marli's own representatives, promotional materials, and field officers about the benefits likely to accrue from farmers' involvement. A set of "Guidelines by Marli Investment Zambia Ltd. for the Production of Jatropha curcas" declare the following advantages:

- Limited labor involvement

- Limited capital investment

- Land fertility

- Seasonal inputs, need only about 60 grams of compound $\mathrm{D}$ fertilizer per tree per year

- Continuous, long harvesting period

- Grow in any type of soil apart from wetland

- Long life span (30 years)

- High production if well managed

- Easily overcome pests and diseases

- Easy to manage

- Easy to safeguard

- Cows and goats do not eat the plants

- Can be planted on same field as other crops (intercropping)

- Increase value of the property the trees are planted on

Explaining his reason for joining, one farmer said he was told that one tree would give him 10,000 Kwacha annually (approximately US\$2) ${ }^{[4]}$, which he called "a life pension."
Another farmer said the company had promised to "bring a big machine for producing diesel, soap, and candles" if he continued cultivating jatropha. Other expectations arose due to some attractive terms in contracts, such as access to loans and annual payments until harvest, and to the diversity of products they could produce. A Chinsali farmer stated the following: "So many people were admiring this thing; even Marli promised to send money for weeding every two years. They promised it would produce soap, manure, airplane fuel."

Based on data from questionnaires, expectations registering high among respondents include terms of the contract, as well as the status that being associated with a large commercial enterprise would bring to the household (Table 2). Yet, despite the commonly stated assumptions about jatropha's ability to thrive under suboptimal environmental and management conditions (low labor, low inputs), relatively few farmers expressed these expectations.

Table 2. Farmer expectations at the time of signing production agreements in Chinsali and Mungwi Districts $(n=60)$.

\begin{tabular}{lcc}
\hline \hline \multirow{2}{*}{ Expectation } & \multicolumn{2}{c}{$\%$ respondents } \\
\cline { 2 - 3 } & Yes & No \\
\hline Significant income from the sale of & 100.0 & 0.0 \\
seeds & & \\
Jatropha requires very little labor & 25.0 & 75.0 \\
Jatropha requires very few inputs & 44.2 & 55.8 \\
$\begin{array}{l}\text { Access to loans by becoming an } \\
\text { outgrower }\end{array}$ & 95.9 & 4.1 \\
$\begin{array}{l}\text { Access to inputs by becoming an } \\
\text { outgrower }\end{array}$ & 86.0 & 14.0 \\
$\begin{array}{l}\text { Receipt of annual payments until the } \\
\text { trees mature }\end{array}$ & 94.0 & 6.0 \\
$\begin{array}{l}\text { Being associated with a large } \\
\text { commercial enterprise would } \\
\text { improve family's social status within } \\
\text { the village }\end{array}$ & 78.8 & 21.2 \\
$\begin{array}{l}\text { That a portion of company proceeds } \\
\text { would be allocated for community } \\
\text { development }\end{array}$ & 85.7 & \\
$\begin{array}{l}\text { That Marli would provide a secure } \\
\text { market for contracted growers }\end{array}$ & 100.0 & \\
\hline
\end{tabular}

More than half of the respondents further indicated that the purported involvement of former president Kenneth Kaunda in the company provided an incentive for getting involved, a result not included in Table 2 as it was not phrased as an expectation per se. When respondents were asked to list the two most important expectations in shaping their decision to become Marli outgrowers, the most frequent answers included access to loans (51.6\% of respondents), followed by a secure market and income from sales (40.3\% of respondents each) and company proceeds for community development (16.1\%). 
Curiously, income from the sale of jatropha seed, presumably the primary reason one would get involved in a jatropha outgrower scheme, was only fourth in importance among farmer incentives for getting involved in Chinsali. This suggests that, until farmers begin to sell, they may be lured by secondary perks as much as or more than the main focus of the activity, often unrealistically, since some farmers indicated they would use loans for activities other than jatropha.

Aside from limited income from sales, the main benefits farmers have received to date include training and seed (79.6\% and $84 \%$ of respondents, respectively). A few farmers also claim to have received pesticides. None of the respondents received loans or cash payments from the company at any time.

\section{Broken promises}

Since 2008, Marli representatives have not been seen in these two districts. Marli stopped all payment to field officers in 2008; after working without pay for up to a year, field officers have also stopped visiting farmers. According to one field officer, "they just pulled out, minus informing us what had happened." Respondents were unaware of any Marli representatives purchasing seed from contracted growers, despite 2 years of yields on some farms. Thus, the pricing of seed and inputs, to be determined at the time of sale, remained unclear at the time of research. Reasons for Marli's disappearance may be due in part to the global economic downturn, given the company's (reportedly unsuccessful) attempt to secure the outside investments needed to expand (and, apparently, also to maintain existing) operations.

Farmer reactions to Marli's disappearance vary. The majority (73.3\%) of respondents said jatropha cultivation was not meeting their expectations due to the absence of a market or any concrete benefits or the poor performance of trees. Half of those claiming that their expectations have been met indicated that they had either sold seed or seen others selling. The other half justified their response on the basis of their expectations of future returns. Eighty percent of farmers claiming to be dissatisfied indicated that they expected future returns, underlying the reasons behind their failure to destroy or completely neglect their investment. A few farmers indicated that they are waiting for further instruction from Marli before taking any action. It should be noted that despite Marli's disappearance and limited market outlets, farmers continue to invest their time in the jatropha fields, with $74 \%$ of respondents indicating that they continue to weed their fields. This willingness to continue protecting their investment contrasts with their anger toward Marli field officers, with farmers in Chinsali threatening to take one of Marli's field officers to court for breach of contractual obligations. Field officers, in turn, made repeated efforts to contact Marli. They were simply told that the company is in a learning phase and to continue their work with farmers, underlying the ease with which company representatives encourage smallholders and field officers alike to bear risk.

\section{Support for the evolution of alternative markets}

In order to support the development of an alternative market for jatropha seed, Dutch NGO SNV has selected jatropha as one of three agricultural enterprises for support in Zambia. Building on their experiences in Mali, SNV is supporting business development skills for farmers and agroenterprises while supporting linkages with other service providers as well as farmer organization and lobbying (Mbago, personal communication; SNV website: http://www.snvworld.org/en/c ountries/mali/Pages/default.aspx). Farmers are trained in jatropha production and marketing, whereas agroenterprise members are trained in business skills and value addition, most notably the processing of jatropha seed into soap tablets and powder. SNV has also supported the establishment of district and provincial biofuel associations to support and help represent the interests of smallholders and provide a counterbalance to the BAZ, which is largely perceived to represent the interests of large investors. According to representatives of the Northern Biofuels Association (NBA), "BAZ, to us smallholders, is prestigious, in the sense that since its conception it has not gone down to the grassroots. It looks at the 'already upstairs people' ... We are very indebted to SNV; without SNV, we wouldn't be." These associations, although very new and still struggling to finance their operations, currently represent the strongest voice advocating for a smallholder-based business model for biofuel feedstock production in Zambia. Although reportedly instrumental in raising awareness among one of the paramount chiefs to resist large-scale land acquisition by foreign investors in the sector (e.g., using maps of chiefdoms to illustrate the size of landholdings at stake), at the time of research the NBA had yet to participate in any meaningful way in national level policy debates.

The oldest and largest of the few enterprises established to date is the Mulondolwa Jatropha Industry in Mungwi. The enterprise produced its first soap in 2008 and was selling in seven retail outlets in the Kasama area. Based on sales records, only 69 farmers sold to the enterprise in 2009 and 57 in the first half of 2010 (at around US\$ 0.20 per kilo, a price that association members claim is too high to be sustained), suggesting that the proportion of Marli outgrowers benefiting from this scheme at the time of research was very small. Yet, according to the business manager, they have the capacity to purchase all of the seed in the district. The NBA also sees this system as more beneficial to farmers than formal contracts, as farmers retain the freedom of choice over whether to continue growing jatropha and to whom to sell. In addition to providing their first market for jatropha seed, 54\% of farmers selling to the local enterprises claim to be receiving technical support from either SNV or the local biofuel association. 
Research into the early responses of farmers to this new-found market helps to posit plausible future developments in land use and livelihoods. Slightly more than half of respondents in Mungwi claimed to have already expanded the area under jatropha in response to the market. The land use changes this involved included conversion of fallow (31\% of respondents claiming to have expanded their jatropha fields), intercropping in a larger area of cropland (25\%), and conversion of food crops (19\%), followed by the conversion of mature forest and replacement planting (12.5\% each). Although the majority of farmers $(68 \%)$ still claim that jatropha is not meeting their expectations due to low price, high labor demands, or low yields, none of these farmers had abandoned their fields due to expectations of future price increases. Furthermore, farmers seem to be investing more in the management of their plantations, with $30 \%$ of respondents saying that they have increased the amount of time spent on jatropha since finding a market. The majority of these households have invested this time on improved management (Table 3). This investment appears to have begun yielding fruits, with higher survivorship relative to the original area planted (94\% of the original number of trees still standing in Mungwi, compared with 67\% in Chinsali) and higher average yields $(110.0 \mathrm{~kg} / \mathrm{ha} / \mathrm{year}$, compared with Chinsali's $55.3 \mathrm{~kg}$ ).

Table 3. Labor allocations among respondents reporting increased labor allocation to jatropha following their first sales.

\begin{tabular}{lc}
\hline \hline Activity & $\begin{array}{c}\% \\
\text { Respondents }\end{array}$ \\
\hline Improved management (weeding, pruning) & 55 \\
Expansion of area under jatropha (nursery & 36 \\
establishment, land clearing, land preparation, & \\
planting) & \\
Marketing existing produce & 9 \\
\hline
\end{tabular}

It is interesting to note that $39 \%$ of respondents in Mungwi claim jatropha to be a man's crop (as opposed to shared), up from $10 \%$ in Chinsali. This suggests that the increased male involvement and control observed in other agricultural commodities as they gain in commercial importance (von Braun and Webb 1989, Darity 1995; A. Wardell and N. Fold, unpublished manuscript) may also be occurring with jatropha.

When asking farmers about actions they were likely to take under different future pricing scenarios, $75 \%$ of respondents indicated they would continue to expand under current prices. Only $44 \%$ of respondents indicated that they would expand if prices were to drop to $750 \mathrm{Kwacha}$ (US\$ 0.15)/kilo, whereas $40 \%$ indicated that they would make no changes. The remainder claimed that they would either reduce the area under cultivation or abandon jatropha cultivation altogether.

\section{Environmental impacts: direct and indirect land use change}

Households were found to allocate an average of 0.71 ha to jatropha, with $90 \%$ of respondents indicating that this is planted in the form of fields rather than as hedgerows or fences. Fifty-four percent of households intercropped jatropha with other food crops, the majority (61\%) with maize but also with groundnut, beans, sweet potato, cassava, and soybean. Although most households avoid intercropping with cassava due to Marli's advice (to avoid the spread of diseases common to the two crops), a few farmers began to practice cassava intercropping after Marli representatives failed to return.

Both direct and indirect land use changes were observed as a result of the integration of jatropha into smallholder farms in Chinsali and Mungwi (Table 4). Direct land use changes occurred because of the integration of jatropha into permanent cropland (either as an intercrop or by displacing food crops), the opening of fallow vegetation less than 15 years of age, or the opening of mature forest to establish jatropha plantations. A small percentage of farmers also reported planting jatropha as fences, hedgerows, or around homesteads, either alone or in conjunction with other planting arrangements. Indirect land use changes were also observed for some households, such as opening new plots in mature forest or fallow to cultivate displaced food crops.

Only $38.8 \%$ of respondents indicated that food crops were displaced from the integration of jatropha into the farming system, either because the jatropha was intercropped in existing cropland or because it was allocated to forest or fallow. Of these, $88.9 \%$ indicated that they opened new land to compensate for the reduction in food crop production ${ }^{[5]}$. Thus, indirect land use change was reported for only $34.9 \%$ of respondents. Of these households, $57.9 \%$ of respondents (n $=19$ ) indicated that new land was opened up in mature forest and $42.1 \%$ in fallow or "cropland" (very young fallow). Figures presented in Table 4 illustrate the implications of these findings for the entire respondent population.

Whereas in Chinsali no respondent felt there were appreciable environmental impacts from jatropha expansion, 56\% of respondents in Mungwi observed appreciable environmental impacts. Observed negative impacts included deforestation and reduced availability of forest products, whereas positive impacts included improved soil fertility. Higher reporting rates for deforestation in Mungwi is interesting given the higher reported incidence of deforestation in Chinsali, a discrepancy which is likely to be explained by higher population densities (and heightened environmental concern stemming from related environmental changes) and higher rates of environmental awareness in areas adjacent to the provincial capital. This interpretation is supported by the sentiments of one Chinsali farmer about the value of displaced forest, namely that before planting jatropha, "there was nothing there; it was 
Table 4. Distribution of different types of direct and indirect land use changes occurring due to jatropha expansion in Chinsali and Mungwi Districts $(\mathrm{n}=60)$.

\begin{tabular}{lcccc}
\hline \hline Land use category & $\begin{array}{c}\text { \% Respondents producing } \\
\text { direct LUC }\end{array}$ & $\begin{array}{c}\text { Avg. area, } \\
\text { direct LUC } \\
\text { (ha) }\end{array}$ & $\begin{array}{c}\text { \% Respondents producing } \\
\text { indirect LUC }\end{array}$ & $\begin{array}{c}\text { Avg. area, indirect LUC } \\
\text { (ha) }\end{array}$ \\
\hline Cropland & 58 & 0.73 & - & - \\
Fallow & 17 & 0.62 & 15 & 0.54 \\
Mature forest & 22 & 0.76 & 20 & 0.72 \\
Other $^{\ddagger}$ & 5 & - & - & - \\
\hline
\end{tabular}

${ }^{\dagger}$ Numbers do not add up to 100 because some respondents reported multiple types of land use change.

${ }^{\ddagger}$ Includes hedgerows or fences and around homesteads.

just forest." As it is well established that farmers in the area rely heavily on forest products for household income (Clarke et al. 1996, Mbata et al. 2002; Mbago, personal communication), this perception may reflect common narratives undervaluing the ecological functions of dry forests. Farmers claiming positive effects on soil fertility explained that groundnuts grow better when intercropped. They also observed that jatropha sheds its leaves all at the same time, enabling them to be incorporated into the soil when preparing the land for planting.

From the figures presented here, for every 1000 ha of jatropha grown on smallholders' fields, one can estimate that approximately 438 ha of mature forest would be cleared for the two districts studied. An estimated additional 267 ha of fallow vegetation at various ages can also be expected to be cleared. To explore the implications of biofuel production on forests in the study site, we estimate the amount of fuel that can be produced per hectare of cleared forest under different smallholder yield scenarios (Table 5). They show the importance of yield in reducing the environmental impacts of biofuel production per unit of fuel. Although this is an important finding for informing strategies for meeting biofuel production targets, it should not be assumed that efforts to improve smallholder yields will automatically reduce net environmental impacts because yield improvements could also induce greater numbers of smallholders to grow feedstock (with its attendant environmental effects) (Angelsen and Kaimowitz 2001, Lee and Barrett 2001, Kaimowitz and Angelsen 2008).

For an analysis of the climate impacts and mitigation potential of this system, please see Achten and Verchot (2011).

\section{Livelihood impacts}

Although livelihood impacts will only become fully manifest over the medium term, early outcomes may be observed through an exploration of the early effects of land use change on food security and returns to labor.

\section{Food security}

In this case study, food security was looked at from multiple perspectives, including the following: (1) the land area under food crops before and after the introduction of jatropha; (2) changes in net food production; (3) changes in the quality of land allocated to food crops, whether due to changes in the land selected for food production or to the effects of jatropha on food crops when intercropped; and (4) loss of revenues and/ or the safety nets that nontimber forest products provide as a result of deforestation and/or forest degradation.

Surprisingly, when looking at the land area dedicated to food crops in the period preceding and following the integration of jatropha into the farming system, we found average increases of $28.6 \%$ and $4.5 \%$ in Chinsali and Mungwi, respectively, on the basis of household survey data (equivalent to 0.38 and 0.12 ha per household). Looking at the same data from a distributional angle, we found $60 \%$ and $24 \%$ of households to exhibit an increase in area under food crops in Chinsali and Mungwi, respectively, and $16.7 \%$ and $36 \%$ of households a decrease. The remaining households exhibited no change in the area under food crops. Although an increase in land dedicated to food crops due to jatropha cultivation seems counterintuitive, it is possible because some households open up new cropland for jatropha and intercrop with food crops in these new fields and other households displace food crops to new areas while intercropping in the original cropland. However, not all of the observed increase can be attributed to jatropha. Inclusion of a follow-up question on the reasons for observed increases in area under food crops suggests that the increase is partially due to jatropha (e.g., to compensate for displaced crops, because jatropha was crowding out food crops in intercropped fields, jatropha creates an opportunity to intercrop) and partially due to independent decisions (e.g., to expand food production, grow new food crops). Observed decreases in the land allocated to food crops were due to the displacement of food crops by jatropha (in cases where 
Table 5. Estimated yield per hectare of mature and degraded forest cleared for biofuel feedstock cultivation (using a seed yield of $3.0 \mathrm{~kg} / \mathrm{liter})$.

\begin{tabular}{ccc}
\hline \hline $\begin{array}{c}\text { Yield scenario } \\
\text { (tons/ha/yr) }\end{array}$ & $\begin{array}{c}\text { Yield of crude jatropha oil per area of } \\
\text { mature forest cleared } \\
\text { (liters/ha) }\end{array}$ & $\begin{array}{c}\text { Yield of crude jatropha oil per area of } \\
\text { mature forest \& fallow cleared } \\
\text { (liters/ha) }\end{array}$ \\
\hline 0.11 & 118 & 73 \\
1.6 & 1718 & 1054 \\
3.0 & 3222 & 1976 \\
\hline
\end{tabular}

${ }^{\dagger}$ The first corresponds to average per-hectare yields in Kasama, where a limited market for seed exists. The second corresponds to published yields for smallholders in neighboring Tanzania (des Grades 2007); Kamal Desai of Marli also estimates $1.5-2.0 \mathrm{~kg} /$ tree by year 4 for contracted Zambian smallholders. The 3.0 figure is the lower end of the yield range (presumed to correspond to smallholder conditions) provided by van Eijck and Romijn (2008) for suboptimal growing conditions in Tanzania.

jatropha was planted as a monoculture or significant amounts of cassava were displaced) as well as labor shortages.

As the tendency to remove cassava from intercropped jatropha fields means that specific food crops may be displaced even when there is no change in area dedicated to food crops, it is important to look also at net changes in food production. For the majority of households $(62.9 \%)$, no change in net food production was observed; the second largest group $(30.6 \%)$ claimed that food production had increased, whereas $6.5 \%$ claimed a decrease. When probing into the reasons behind these changes in Chinsali District, significant numbers of respondents gave reasons unrelated to jatropha (e.g., independent decisions to expand cropping area), whereas most of the decrease was ascribed to the expansion of jatropha. Furthermore, one-fifth of farmers in Chinsali and one-third of those in Mungwi who are now selling to local enterprises felt that engaging in jatropha cultivation meant they had less time to spend on their food crops. Therefore, the negative effects on food production, although observed in only a small proportion of households, should nevertheless be given due attention. Furthermore, for households declaring no change in net food production as a result of jatropha cultivation, pressure due to limited labor was experienced by some households at harvest time. For most households, intercropping in the early years was said to be possible without any competition with food crops.

As far as land quality is concerned, $76.5 \%$ of respondents ( $\mathrm{n}$ $=17$ ) claiming to have opened new land as a result of displaced food crops said the quality of land was unchanged. Most of the other respondents (17.6\% of all respondents) actually reported improvements in land quality for food crops, improvements that were claimed to be responsible for observed increases in net food production for some households. This may be explained by the fact that some households planted jatropha in cropland that was already "tired," selecting land of higher quality in old fallow or mature forest to grow their food crops. Although this trend is encouraging news for food security, it may compromise the viability of jatropha that, under Zambian conditions, seems to require ideal growing conditions to produce reasonable yields. Thus, as the sector evolves, the possibility that the tension between food and fuel will increase over time should not be ruled out. Furthermore, with $35.3 \%$ of newly established cropland further away from homesteads than the original plots, increased labor burden cannot be ruled out. Interestingly, one farmer grew jatropha in otherwise exhausted agricultural land for the purpose of recuperating this land for future food crops, a use that has been much posited in the literature (FAO 2010; Ogunwole et al., n.d.) but seldom observed to date.

As for food security impacts resulting from the clearing of forest areas for jatropha or displaced food crops, only $21 \%$ of those opening mature forest or fallow said they had been obtaining forest products, such as fruits, mushrooms, caterpillars, charcoal, or fodder, from these areas. This contrasts with the observation that there is no major push for farming as an enterprise in Northern Province because of the high value of forest products, such as caterpillars and mushrooms (Mbago, personal communication). Observed changes in the availability of these forest products were invariably reported to be small, largely because the area of remaining forest is considered to be significant. Such food security effects seem to be negligible for the study site.

\section{Returns to labor}

One of the main considerations with outgrower schemes for emerging industries, where production models have yet to be tested and there is therefore considerable risk, is returns to labor. How much time and effort have farmers invested, and for what benefit?

Households investing in jatropha cultivation were found to invest considerable amounts of time in nursery management (primarily watering), land preparation and planting (including 
the clearing of all trees and stumps and the digging of individual planting holes), weeding and the establishment of fire breaks, pruning, harvesting, and postharvest handling. Some respondents noted that land preparation for jatropha requires considerably more time than for other food crops given the stump clearing requirement, forcing farmers to grow jatropha in permanent fields rather than as part of the chitemene system. Families claim to have weeded the jatropha plantation an average of 3.5 years out of 4 , but other management activities have suffered in the absence of regular extension services and markets. Pruning, for example, an essential activity for maximizing yields, has been done only once for most households. Depending on whether jatropha is planted as an intercrop or monoculture, additional weeding (over and above what would be carried out for food crops) is required once or twice annually.

In Chinsali, additional man-days ${ }^{[6]}$ were calculated for the two most labor-demanding activities per household. Although difficulties in informant recall make it difficult to rely on these figures, they provide a general idea of the level of effort invested without generating meaningful returns. Families estimated to have spent an additional 199 days in the past 4 years on the top two labor-demanding activities for jatropha (including labor from adults and children), which translates into 6.5 months of effort with no returns for growers in Chinsali (and much more if all management activities are taken into account). These figures should be interpreted with caution due to the significant variability in responses and difficulty of recall. They also should not be taken as representative of a viable smallholder jatropha industry, as only two of the many management activities were captured and many regular management activities are neglected in the absence of a market. For example, some households register no effort to harvest due to poor market or no yield. Although perceptions of the most labor-demanding activities varied by household, the most commonly mentioned activities in Chinsali included land preparation and weeding, and in Mungwe, weeding and harvesting.

Labor investments for harvesting and postharvest handling were also calculated for Mungwe farmers, who have a better idea of costs due to the presence of a market, albeit a limited one (thus, causing many farmers to leave a portion of their harvest in the field). Farmers claimed to spend on average 20.7 and 12.1 days on harvest and postharvest processing, respectively. With an average income to date being in the order of 73,688 Kwacha (approximately US\$15.74), returns to labor can be assumed to be considerably less than US $\$ 0.06$ per day. The maximum income received by any of the farmers interviewed was roughly twice the average, at US\$ 30.61 . If informant recall data is any reflection on reality, then local enterprises must grow considerably or alternative buyers must play a bigger role if this is to be a viable choice for farmers.
Although low market price is partially responsible for these low returns, low yields also help to explain poor returns to labor. Per hectare yields to date have been painfully low, from 0 to $400 \mathrm{~kg}$ per year. This has been due to a number of factors, among them poor germplasm, destruction of plantations by fire, poor management (infrequent weeding and pruning), and pests and disease (of which termites are by far the most destructive). Although one farmer reported to be experimenting with the application of ash at the base of jatropha plants to control termites, the majority of farmers reporting significant reductions in yield as a result.

Ironically, despite these low returns, 35\% of farmers noted effects on livelihoods, the bulk of which were positive. These include increased income, ability to purchase basic goods, local manufacturing and sales of soap, the provision of organic fertilizer, and the benefits of a perennial crop for which initial labor investments continue to yield returns over time. It is interesting to note that returns can be almost negligible yet still provoke a positive reaction from farmers due to levels of poverty or the promise of future returns. This is aptly captured by reasons given by one farmer for expanding his plantation despite earning the equivalent of only US\$ 2.45 for one 50$\mathrm{kg}$ bag of seed: "I can leave the plantation to my children; even if it is 1,000 Kwacha, I can buy a razor blade."

It is important to note that children contributed significantly to most on-farm jatropha management activities, with $34 \%$ of all time invested in Chinsali and $31.7 \%$ in Mungwe provided by children (calculated as total time invested rather than in work equivalents). Although this may be considered typical of agricultural households, its significance is likely to increase as markets improve and households invest more time in the management of their plantations. A number of farmers reported having engaged communal labor, and, in one case involving an elderly woman, school children, to carry out the more labor-demanding activities (weeding, harvesting), in which case in-kind payment (notably in food) was more common than cash payment. It is important to note that jatropha is also generating employment for select households involved in local enterprises, where the value added to jatropha seed from the processing of soap far exceeds that for fuel (Maona, personal communication). However, the number of beneficiary households is at present too few to make a meaningful impact on the local economy.

\section{DISCUSSION AND CONCLUSIONS}

Although biofuels have been touted as a solution to rural poverty in Zambia and sub-Saharan Africa at large, experience to date highlights the many uncertainties underpinning these claims in an industry that is still trying to stand on its own two feet. This case profiled experiences with smallholder-based jatropha production in the largest outgrower scheme in Zambia, Marli Investments. Findings highlight problems related to the contractual agreements between farmers and 
Marli, as well as the early social and environmental impacts accruing from this scheme. Farmers, for the most part, approached these outgrower agreements with high expectations and minimal awareness of the possible risks associated with returns on investment or company control over pricing and land use. Agreements were found to be signed by farmers but not the company, resulting in one-sided contractual obligations. This, together with provisions requiring farmers to keep land under jatropha for 30 years and sell only to Marli, and allowing Marli to set prices one-sidedly, highlights the potentially exploitative nature of these agreements. An analysis of farmer expectations at the time of signing contracts helps to explain why farmers commit to agreements carrying such significant risks. Findings suggest that the promise of loans, secure markets, and company proceeds for "community development" were prominent factors encouraging farmer participation, with income from the sale of seed of only secondary importance. This illustrates the ease with which farmers may be lured by secondary perks, overshadowing the imbalance between core commitments and benefits. With contracts of 30 years' duration, this raises concerns that farmers can be easily lured into unfavorable long-term agreements with promises of short-term returns that are hard to turn down. With Marli failing to live up to most promises and disappearing altogether in 2008, the risks of such agreements are very real indeed.

Observed environmental impacts are also of concern, particularly given the failure of meaningful benefits to materialize. Significant land use changes, both direct and indirect, were observed as a result of the integration of jatropha into smallholder farms. Direct land use changes occurred due to the integration of jatropha into permanent cropland, the opening of fallow vegetation or the opening of mature woodland. Indirect land use changes were also observed in many households as new plots were opened in fallow or mature forest to offset food crop displacement. Informant recall data suggest that $44 \%$ of jatropha expansion occurs at the expense of mature miombo in the study site, and $27 \%$ at the expense of fallow. With extremely low yields, one can expect the environmental price per unit of biofuel to be extremely high under conditions where smallholders receive minimal technical and financial support.

Results from the evaluation of food security effects, although highly variable between households, are more promising. Whereas up to $36 \%$ of households (in Mungwi) were found to experience reductions in land area dedicated to food crops and $6.5 \%$ claimed a decrease in net food production due to the displacement of food crops or competition for scarce labor, food production proved remarkably resilient in the face of increased competition between different land uses. The average household land area dedicated to food crops exhibited average increases of $28.6 \%$ and $4.5 \%$ in Chinsali and Mungwi Districts, respectively, due to the opening of new cropland for jatropha in conjunction with intercropping in the newly opened areas or the original cropland. Increases in net food production were also observed for some households due to the tendency to establish jatropha in degraded plots while deflecting food crops to more fertile areas. That said, returns to household labor have proven to be pitifully low. Land preparation, cultivation, harvest, and postharvest handling all require high levels of labor investment, yet low yields and limited market outlets resulted in limited to no returns for investing households. Although SNV support to alternative markets in the form of local industries has partially alleviated marketing constraints, the amount of seed purchased by these fledgling industries was, at the time of research, much lower than that required to sustain the number of outgrowers contracted by Marli.

To conclude, the risks of an unproven feedstock and biofuel industry in Northern Province have been borne to a large extent by smallholder farmers who can least afford it rather than by investors quietly promoting the scheme from behind the scenes. The very disappointing outcomes highlighted in this paper put into question the conclusion that the problems associated with large-scale land acquisitions for biofuels will be automatically addressed through industry-led smallholder feedstock production schemes. They also undermine key policy aims related to rural livelihoods and environmental sustainability in the Zambian biofuel sector, and beg the question of whether jatropha as a feedstock and the institutional model employed in its production (outgrower schemes) should be further pursued in Zambia. Yet in the event that decisions are made to continue promoting or experimenting with them, action is urgently needed to reduce the livelihood risks to smallholders, and to harness the potential of the biofuel industry in supporting rural livelihoods while reducing negative impacts on the environment. This includes, minimally, interventions in three key areas: (1) minimizing risk to smallholders; (2) supporting the evolution of alternative markets and more flexible, voluntary forms of farmer engagement in the biofuels market; and (3) minimizing environmental costs.

To minimize risk to smallholders, a number of key actions would be required. Efforts to raise awareness among smallholders on the (potentially limited) benefits and (potentially significant) risks of engaging in long-term contracts with investors, and to improve farmers' legal literacy, are critical. Regulatory efforts are also needed to keep companies from expanding beyond their means (and thus contracting more growers than they can realistically support in terms of services and market outlets) until feedstocks and business models are proven to be viable and financial capacity is ensured. This can include setting standards for the operations of investors, requiring companies to demonstrate sustainable demand for their product prior to engaging outgrowers (see also ECI Africa Consulting 2006) and keeping an eye on 
contract terms (e.g., contract duration, grading, weighing and pricing practices, and potential for indebtedness) and the processes through which contracts are negotiated. Monitoring of investor performance is another important ingredient to sustainable and equitable sector evolution, including, minimally, impacts on food security and the extent to which companies have met their contractual commitments to outgrowers. Monitoring is especially important given the likelihood that effects will change over time as plantations mature (for example, crowding out food crops), the sector evolves (e.g., with more secure markets inducing changes in land and labor allocation and gender dynamics at household level), and competition over land and labor intensifies.

The high level of risk borne by local communities under both outgrower schemes and industrial-scale business models (Schoneveld et al. 2011, Obidzinski et al. in press), in terms of returns to land and labor, as well as the retention of decisionmaking authority over the allocation of these limited resources, suggests that efforts are also needed to nurture the evolution of alternative, more voluntary markets for smallholders. Support to small-scale enterprises for the production of biodiesel and other products, and to farmers' organizational capacity (to support market linkages, for example, or to seek redress in the face of grievances), may be the best means to support smallholder participation in the industry. However, the scope and scale of support required to make this a meaningful model for producing the volumes of biofuel required nationally and at minimum cost to the environment means that concerted government support in the form of credit, extension services, and market linkages is likely to be needed.

Regarding the environmental impacts, findings from this study and the climate mitigation article by Achten and Verchot (2011) suggest that the purported climate benefits of biofuels are unlikely to accrue under smallholder-based jatropha production in the absence of significant yield improvements. Yet the potential livelihood benefits from smallholder production, including the possibility of land remaining in the hands of customary rights holders and the increased freedom of choice that comes with it, suggest that mechanisms to deliver yield-enhancing services to smallholders (high-quality extension services, low-risk forms of credit, market support) should be explored. There is evidence to suggest that efforts to screen and coordinate the actions of companies to avoid side-buying and encouraging codes of conduct for investors and farmers can help ratchet up services to farmers and thus yields (ECI Africa Consulting 2006, Tschirley and Kabwe 2007). Monitoring of environment impacts, particularly carbon balances, is also essential, to ensure the purported climate mitigation benefits of biofuels actually materialize, and therefore to minimize the risk of markets drying up.

\section{RESPONSES TO THIS ARTICLE}

Responses to this article are invited. If accepted for publication, your response will be hyperlinked to the article. To submit a response, follow this link. To read responses already accepted, follow this link.

\section{ACKNOWLEDGMENTS}

This paper has been produced with the financial assistance of the European Union, under a project entitled, "Bioenergy, sustainability and trade-offs: Can we avoid deforestation while promoting bioenergy?" The objective of the project is to contribute to sustainable bioenergy development that benefits local people in developing countries, minimizes negative impacts on local environments and rural livelihoods, and contributes to global climate change mitigation. The project is managed by the Center for International Forestry Research and implemented in collaboration with the Council on Scientific and Industrial Research (South Africa), Joanneum Research (Austria), the Universidad Autónoma de México, and the Stockholm Environment Institute. The views expressed herein can in no way be taken to reflect the official opinion of the European Union. In addition to acknowledging the financial support of the EC, the authors would like to express their gratitude to those who took time out of their busy schedules to share their knowledge and experience with the research team. These include, among others, government representatives from the Ministry of Energy (Charles Mulenga), the Energy Regulation Board (Dr. Nyamazana and Mwenya Bwalya), the Ministry of Lands (Mike Goma and Barnaby Mulenga), the Zambia Development Agency (Matimba Changala, Ms. Mumba, and Lovemore Simwanda), CEEC (Mable Mungomba and Ricardo Mupenga), and local government offices (C. Chilekwa, Maximo Chitambi, Frank Mwambaz, Samuel Phiri); industry representatives (Martina Bergschneider, Guy Changole, Tyson Chisambo, Kamal Desai, Guy Havemann, Arjan Muijs, Sally Ross, Prof. Thomson Sinkal, and Wolly Vermaak); civil society representatives (Bwendo Kabanda, Namakau Maswenyehu, Mundia Matongo, Sarah Mbago, Kapalu Muswala, Albert Mutale, and Jennifer Willis); representatives of farmer organizations (George Kasonde Chilikuma, Mr. Mfula, and Martin Pride Mwelwa); and independent consultants (Professor Yamba). The authors are also grateful to those who assisted with various stages of fieldwork, and to Margaret Skutsch, Andrew Wardell, Pablo Pacheco, and independent reviewers for the valuable comments provided on earlier drafts.

\section{LITERATURE CITED}

Abwino, E. N., and H. Rieks. 2007. Out-grower system through contract farming: Zambia. GroLink/Agro Eco Report no. 2007-04. 
Achten, W. 2010. Sustainability evaluation of biodiesel from Jatropha curcas L.: a life cycle oriented study. Dissertation. Katholieke Universiteit Leuven, Heverlee, Belgium.

Achten, W. M. J., W. H. Maes, R. Aerts, L. Verchot, A. Trabucco, E. Mathijs, V. P. Singh, and B. Muys. 2009. Jatropha: from global hype to local opportunity. Journal of Arid Environments 74(2010):164-165. http://dx.doi.org/10.10 16/j.jaridenv.2009.08.010

Achten, W. M. J., and L. V. Verchot. 2011. Implications of biodiesel-induced land-use changes for $\mathrm{CO} 2$ emissions: case studies in tropical America, Africa, and southeast Asia. Ecology and Society16(4): 14. http://dx.doi.org/10.5751/ES-0 4403-160414

Angelsen, A., and D. Kaimowitz, editors. 2001. Agricultural technologies and tropical deforestation. CAB International, Nairobi, Kenya. http://dx.doi.org/10.1079/9780851994512.0000

Brittaine, R., and N. Lutaladio. 2010. Jatropha, a smallholder bioenergy crop: the potential for pro-poor development. FAO, Rome.

[CCJDP] Catholic Centre for Justice, Development and Peace. 2006. Growing poverty: the impact of out-grower schemes on poverty in Zambia. The Catholic Centre for Justice, Development and Peace, Lusaka, Zambia.

Chidumayo, E. 1987. A shifting cultivation land use system under population pressure in Zambia. Agroforestry Systems 5:12-25. http://dx.doi.org/10.1007/BF00046411

Clarke, J., W. Cavendish, and C. Coote. 1996. Rural households and miombo woodlands: use, value and management. Pages 101-135 in B. C. Campbell, editor. The miombo in transition: woodlands and welfare in Africa. Center for International Forestry Research, Bogor, Indonesia.

Cliggett, L., E. Colson, R. Hay, T. Scudder, and J. Unruh. 2007. Chronic uncertainty and momentary opportunity: a half century of adaptation among Zambia's Gwembe Tonga. Human Ecology 35(1):19-31. http://dx.doi.org/10.1007/s1074 5-006-9080-7

CO2. 2010. Available at: http://www.menergycorp.com/ PILOT.html (accessed 18 August 2010, but no longer available).

[CSBF] Civil Society Biofuels Forum. 2009. Report on the Analysis of the Policies and Regulatory Arrangements of the Liquid Biofuel Industry in Zambia. Civil Society Biofuels Forum, Lusaka, Zambia.

CSBF. 2010. Situation Analysis of the Biofuels Industry in Zambia. Civil Society Biofuels Forum, Lusaka, Zambia.

Darity, W. 1995. The formal structure of a gender-segregated low-income economy. World Development 23(11):1963-1968. http://dx.doi.org/10.1016/0305-750X(95)00082-N des Grades, E. 2007. An exploration of the potential of producing biofuels and the prospective influence of biofuels production on poverty alleviation among small-scale farmers in Tanzania. Dissertation. University of Bonn, Bonn, Germany.

Desai, K. 2009. Marli Investments (Z) Ltd. Presentation given at the COMPETE conference in Brussels, November, 2009.

Department of Minerals and Energy. 2007. Biofuels industrial strategy of the Republic of South Africa. Department of Minerals and Energy, Cape Town, South Africa.

ECI Africa Consulting. 2006. Review of horticultural outgrower schemes in Mozambique, Final Report to the Government of Mozambique and the World Bank. ECI Africa Consulting, Johannesburg, South Africa and AgriDev Consult, Lusaka, Zambia.

Ferguson, J. 1999. Expectations of modernity: myths and meanings of urban life on the Zambian Copperbelt. University of California Press, Berkeley, California, USA.

[FIAN] FoodFirst Information and Action Network. 2010. Land grabbing in Kenya and Mozambique. FIAN, Heidelberg, Germany.

[FAO] Food and Agriculture Organization of the United Nations. 2010. Jatropha: a smallholder bioenergy crop, the potential for pro-poor development. Integrated Crop Management 8-2010. FAO, Rome, Italy.

Freeman, L., J. Lewis, and S. Borreill-Freeman with C. Wiedmer, J. Carter, N. Clot, and B. Tchoumba. 2009. Free, prior and informed consent: implications for sustainable forest management in the Congo Basin. Pages 319-334 in L. German, A. Karsenty, and A.-M. Tiani, editors. Governing Africa's forests in a globalized world. Earthscan, London, UK.

Freim, L. O. 2008. How will small-scale farmers in Zambia benefit from growing of Jatropha? Thesis. Norwegian University of Life Sciences, Ås, Norway.

German, L., and G. Schoneveld. In press. Analysis of the legal and institutional framework for biofuel investment and expansion in Zambia. CIFOR, Bogor, Indonesia.

GEXSI. 2008. Global market study on jatropha: case studies. Prepared for the World Wide Fund for Nature, London/Berlin, May 8, 2008.

Glover, D. 1990. Contract farming and outgrower schemes in East and southern Africa. Journal of Agricultural Economics 41:303-315. http://dx.doi.org/10.1111/j.1477-9552.1990.tb00648. $\underline{\mathrm{x}}$

Glover, D., and K. Kusterer. 1990. Small farmers, big business: contract farming and rural development. Macmillan, London, UK.

Heller, J. 1996. Physic nut - Jatropha curcas L.: promoting the conservation and use of underutilized and neglected crops. 
Dissertation. Institute of Plant Genetic and Crop Plant Research, Gatersleben, Germany and International Plant Genetic Resource Institute, Rome, Italy.

Kaimowitz, D., and A. Angelsen. 2008. Will livestock intensification help save Latin America's tropical forests? Journal of Sustainable Forestry 27(1):6-24.

Kakeya, M., Y. Sugiyama, and S. Oyama. 2006. The chitemene system, social leveling mechanism, and agrarian changes in the Bemba villages of northern Zambia: an overview of 23 years of "fixed-point" research. African Study Monographs 27(1):27-38.

Lamb, G., and L. Muller. 1982. Control, accountability and incentives in a successful development institution. World Bank Working Paper no. 550. World Bank, Washington, D.C., USA.

Lee, D. R., and C. B. Barrett, editors. 2001. Tradeoffs or synergies? Agricultural intensification, economic development and the environment. CAB International, Wallingford, UK. http://dx.doi.org/10.1079/9780851994352.0000

Loos, T. K. 2009. Socio-economic impact of a jatropha-project on smallholder farmers in Mpanda, Tanzania: case study of a public-private-partnership project in Tanzania. Thesis. University of Hohenheim, Stuttgart, Germany.

Mathews, J. A. 2007. Biofuels: what a biopact between North and South could achieve. Energy Policy 35:550-3570. http://d x.doi.org/http://dx.doi.org/10.1016/j.enpol.2007.02.011

Mbata, K. J., E. M. Chidumayo, and C. M. Lwatula. 2002. Traditional regulation of edible caterpillar exploitation in the Kopa area of Mpika District in northern Zambia. Journal of Insect Conservation 6(2):15-130. http://dx.doi.org/http://dx.doi. org/10.1023/A:1020953030648

[MEWD] Ministry of Energy and Water Development. 2008. The biofuels industry strategy (draft). Ministry of Energy and Water Development, Lusaka, Zambia.

Moore, H. L., and H. Vaughan. 1994. Cutting down trees: gender, nutrition and agricultural change in the Northern Province of Zambia, 1890-1990. Heinemann, Portsmouth, UK.

Obidzinski, K., R. Andriani, H. Komarudin, and A. Andrianto in press. Environmental and social impacts of oil palm plantations and their implications for biofuel production in Indonesia. Ecology and Society.

Ogunwole, J. O., J. S. Patolia, D. R. Chaudhary, A. Ghosh, and J. Chikara. No date. Improvement of the quality of a degraded entisol with Jatropha curcas L under an Indian semi arid condition. Available at: http://www.jatropha.pro/PDF\% 20bestanden/Patolia_-_Soil_Structure_Improvement\%5B1\% 5D.pdf (accessed Sept 21, 2010).
Porter, G., and K. Phillips-Howard. 1997. Comparing contracts: an evaluation of contract farming schemes in Africa. World Development 25(2):227-238. http://dx.doi.org/10.1016/ S0305-750X(96)00101-5

República de Moçambique. 2009. Resolução no. 22/2009, Política e Estratégia de Biocombustíveis. República de Moçambique, Maputo, Mozambique.

Schoneveld, G. C., L. A. German, and E. Nutakor. 2011. Landbased investments for rural development? A grounded analysis of the local impacts of biofuel feedstock plantations in Ghana. Ecology and Society 16(4): 10. http://dx.doi.org/10 $.5751 /$ ES-04424-160410

Sprague, D. S., and S. Oyama. 1999. Density and distribution of citemene fields in a Miombo woodland environment in Zambia. Environmental Management 24(2):273-280. http://d x.doi.org/http://dx.doi.org/10.1007/s002679900232

Stromgaard, P. 1984. Field studies of land use under chitemene shifting cultivation, Zambia. Geografisk Tidsskrift 84:78-85.

Stromgaard, P. 1986. Early secondary succession on abandoned shifting cultivator's plots in the miombo of South Central Africa. Biotropica 18(2):97-106. http://dx.doi.org/10. 2307/2388751

Stromgaard, P. 1988. Soil and vegetation changes under shifting cultivation in the miombo of East Africa. Geografiska Annaler 70(B)3:363-374. http://dx.doi.org/10.2307/490337

Tschirley, D., and S. Kabwe. 2007. Cotton in Zambia: assessment of its organization, performance, current policy initiatives, and challenges for the future. Food Security Research Project Working Paper No. 26. Lusaka, Zambia.

van Eijck, J., and H. Romijn. 2008. Prospects for Jatropha biofuels in Tanzania: an analysis with strategic niche management. Energy Policy 36:311-325. http://dx.doi.org/10 $.1016 /$ j.enpol.2007.09.016

von Braun, J., and R. Meinzen-Dick. 2009. "Land grabbing” by foreign investors in developing countries: risks and opportunities. Policy Brief No. 13. IFPRI, Washington, D.C., USA.

von Braun, J., and P. J. R. Webb. 1989. The impact of new crop technology on the agricultural division of labor in a West African setting. Economic Development and Cultural Change 37(3):513-534. http://dx.doi.org/10.1086/451740

${ }^{[1]}$ In contract farming schemes, firms substitute or supplement company production of agricultural commodities with purchases from local farmers through contracts (Glover and Kusterer 1990:1-2).

${ }^{[2]}$ With low tree survival rates on some farms due to fire, termites, and variable levels of management, it is difficult to determine the accuracy of these figures. 
${ }^{[3]}$ Side-selling refers to the practice in which contracted growers sell to others offering a better price, despite contractual terms requiring exclusive sale to contracting entity.

${ }^{[4]}$ Another farmer said he was promised 25,000 Kwacha per tree.

${ }^{[5]}$ Yet when probing into the primary reasons for opening new land, although more than $75 \%$ of responses suggested linkages to jatropha (e.g., to compensate for displaced crops, because jatropha was crowding out the intercropped maize), independent decisions were also cited (e.g., to expand food production, to secure claims to land). The magnitude of indirect land use change must therefore be interpreted with caution.

[6] "Man-days" were calculated by adding together the total number of hours invested by men, women, and children in each household, and dividing this by 8 (hours in a day). For children, no age-adjusted estimates were done because the aim is not to identify total amount of work done but rather the net burden on household members. 